\title{
STUDI TEORITIS: STRUKTUR DAN SIFAT POLIFURAN TERSUBSTITUSI SEBAGAI SEMIKONDUKTOR DENGAN MENGGUNAKAN PROGRAM PM3
}

\author{
Lazulva \\ Program Studi Pendidikan Kimia, Universitas Islam Negeri SUSKA Riau \\ Jurusan Kimia, Fakultas Matematika dan Ilmu Pengetahuan Alam, Universitas Andalas \\ Email: lazoelva_1154@yahoo.com
}

\begin{abstract}
ABSTRAK
Telah dilakukan penelitian untuk mempelajari struktur dan sifat elektronik dari polimer furan dan turunannya (disubstitusi) dengan jumlah cincin furan $\mathrm{n}=20$ dengan menggunakan program PM3. Substituen yang digunakan dalam penelitian ini berupa atom atau molekul radikal pada posisi ujung. Subtituen yang dipelajari adalah fenil $(\mathrm{Ph})$, radikal heksahalobenzena $(-\mathrm{Z})$, radikal pirol (Py) dan tiofen (T).. Masukan data awal furan adalah sudut ikatan awal untuk $\mathrm{C}=\mathrm{C}-\mathrm{C}=105^{\circ}, \mathrm{C}=\mathrm{C}-\mathrm{H}=120^{\circ}, \mathrm{H}-\mathrm{C}-\mathrm{C}=$ $135^{\circ}, \mathrm{H}-\mathrm{C}-\mathrm{O}=123.872^{\circ}, \mathrm{O}-\mathrm{C}=\mathrm{C}=116^{\circ}$, torsion angle $=0^{\circ}$ dan panjang ikatan $\mathrm{C}=\mathrm{C}, \mathrm{C}-\mathrm{C}=1,4 \AA$ $1,408 \AA$ dan $\mathrm{C}-\mathrm{H}=1$ A. Dalam penelitian ini digunakan komputasi secara RHF ( Restrical Hartree Fock) dengan pengoptimasi Polak Ribiere. Optimasi dilakukan dengan ketentuan berikut: spin multiplicity = 1; charge $=0$; convergence limit $=0,001$; iterration limit $=50$; dan gradien $0,01 \mathrm{kCal} / \mathrm{mol} . \AA$. Luaran data (dalam keadaan optimal) yang dibutuhkan adalah Binding Energy (BE adalah energi ikatan antar atom-

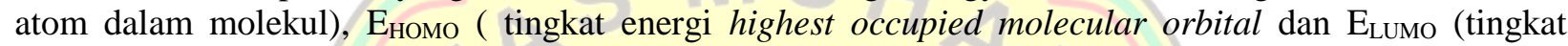
energi lowest occupied molecular orbital). Sifat penghantar polimer ditentukan dari nilai $\Delta \mathrm{E}$ atau ( $\mathrm{E}_{\text {gap }}$ ). Nilai $E_{g a p}$ suatu konduktor, semikonduktor dan isolator berturut-turut adalah $\langle 1,0 \mathrm{eV} ; 1,0-3,0 \mathrm{eV}$; dan $\rangle$ $3 \mathrm{eV}$. Hasil pengoptimasian struktur turunan polifuran memperlihatkan bahwa seluruh substituen yang digunakan dapat menurunkan nilai band gap $\left(\mathrm{E}_{\text {gap }}\right)$ polifuran. Nilai band gap $\left(\mathrm{E}_{\text {gap }}\right)$ ternyata dipengaruhi oleh jumlah cincin furan yang berikatan membentuk polimer. Penurunan nilai band gap yang signifikan terjadi pada jumlah monomer furan $n=1$ s.d 10 .
\end{abstract}

\section{PENDAHULUAN}

Sejak beberapa dekade terakhir, polimerpolimer yang mempunyai ikatan pi terkonjugasi telah dipelajari. Hal ini berkaitan dengan dugaan adanya sifat elektronik dan sifat optik pada senyawa tersebut [1]. Polimer terkonjugasi murni merupakan bahan semikonduktor yang dapat didoping sehingga dapat meningkatkan sifat hantarannya menyerupai sifat hantaran logam, dan tetap mempertahankan sifat mekanik dan prosessibilitas dari polimer. Penggunaan material ini menawarkan ruang lingkup yang cukup luas, diantaranya dalam perlengkapan - perlengkapan elektronik, baterai, dioda emisi cahaya, laser dan sel surya. Dengan demikian seorang peneliti dapat melakukan penelitian dimanapun dia inginkan. Disamping itu peneliti juga dapat mengumpulkan data sebanyak yang ia butuhkan serta mengekstrak informasi berharga dari data yang telah diolah [2].
Sehubungan dengan sifat elektroniknya, banyak ahli menyatakan bahwa polimer-polimer dengan ikatan $\pi$ terkonjugasi dan mengikat atomatom belerang dapat difungsikan sebagai bahan semikonduktor atau konduktor. Forni et al., menemukan bahwa sifat-sifat dari oligomer Tiofen dapat dikorelasikan dengan sifat-sifat polimernya [3]. Nabutoki \& Koezuka memprediksikan bahwa oligomer-oligomer dengan struktur XnYnXn mungkin untuk dikembangkan sebagai semikonduktor baru, dimana $\mathrm{x}$ adalah Tiofen, $\mathrm{y}$ adalah pirol dan $\mathrm{n}=3$ [4]. Eka (1999) menyelidiki bahwa oligomer Tiofen mempunyai nilai energi transisi elektronik (Egap) mendekati $3 \mathrm{eV}$. Sedangkan syarat untuk suatu bahan semi konduktor energi transisi elektroniknya mendekati $1 \mathrm{eV}$ dan untuk sebuah konduktor energi transisi elektroniknya mendekati nol [5]. Diantara sekian banyak polimer dengan ikatan terkonjugasi, polifuran merupakan salah satu material yang sangat 
menarik karena ia dapat digunakan sebagai sensor kelembaban. Hal ini disebabkan oleh sifatnya yang sangat sensitif terhadap kelembaban dan sifat tahanan listrik yang menurun dengan dengan cepat serta dapat balik lagi apabila ada kontak dengan udara lembab / embun [6].

Tahun 2004, Angelca et al. menyelidiki nukleasi dan mekanisme pembentukan polifuran ditinjau dari pengaruh elektrolit dan jumlah monomer dalam asetonitril. Penelitian ini bertujuan untuk mencari hubungan antara nukleasi dan mekanisme pembentukan polifuran dengan parameter dalam proses polimerisasi yaitu tegangan yang diperlukan, konsentrasi monomer dan media elektrolit yang digunakan [7].

Dalam mengoptimasi geometri monomer dan oligomer-oligomer Furan dengan metoda mekanika kuantum semiempiric (guna melihat kaitan struktur dengan sifat elektroniknya) maka panjang dan sudut ikatan yang tepat antara atomatom penyusunnya perlu ditentukan. Disini diperlukan data X-ray tentang panjang dan sudut ikatan senyawa sebagai pembanding. Akhirnya, dari struktur molekul yang optimal ditentukan sifat elektronik dari monomer dan oligomeroligomer Furan serta turunannya dalam konformer anti dari geometri optimalnya. Dari sini didapatkan korelasi antara struktur dan sifat elektronik, seperti band gap dan sifat transisi elektroniknya, sehingga dari data tersebut bisa diketahui sifat polifuran ataupun turunannya.

\section{METODOLOGI PENELITIAN}

Prosedur kerja terdiri atas tahapan sebagai berikut:

\section{a) Membuat masukan data.}

Ada 2 jenis masukan data, yaitu koordinat atom-atom penyusun molekul dan parameter atom. Untuk membuat koordinat atom penyusun molekul, misalnya untuk furan maka langkah yang dilakukan adalah klik menu build, pilih default element, lalu klik, sehingga muncul kotak dialog element table. Dalam kotak dialog tersebut klik unsur $\mathrm{C}$, lalu klik close sehingga muncul kembali jendela yang aktif.Kemudian lakukan hal yang sama untuk mengambil unsur $\mathrm{O}, \mathrm{H}$ dan unsur-unsur lainnya.

Pada jendela aktif, klik di sembarang tempat, kemudian hubungan masing-masing unsur $\mathrm{C}$ dan $\mathrm{C}, \mathrm{C}$ dan $\mathrm{O}$ serta $\mathrm{C}$ dan $\mathrm{H}$, sehingga didapatkan bentuk siklik seperti yang diinginkan (Dalam siklik furan tersebut dibiarkan salah satu ikatan C-O putus). Atur panjang ikatan dengan cara klik select, klik gambar yaitu pada garis, klik menu edit, pilih set bond length, sehingga muncul kotak dialog set bond length. Isikan panjang ikatan yang diinginkan lalu klik $O K$. Setelah semua sudut dan panjang ikatan sesuai dengan yang diperkirakan sebagai masukan awal, baru ikatan C-O yang terputus tadi dihubungkan. Dan akhirnya didapatkan keadaan awal yang sesuai dengan Gambar 1.

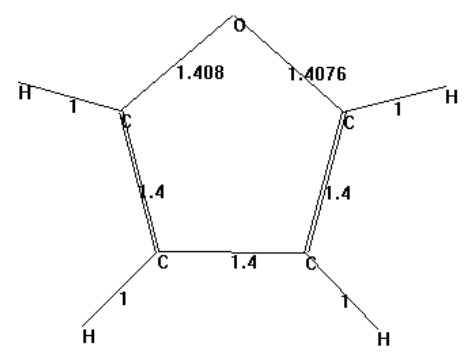

\section{Gambar 1. Geometri awal Atom-atom dalam Furan, panjang dalam $\AA$}

Dalam penelitian ini, sudut ikatan awal untuk $\mathrm{C}=\mathrm{C}-\mathrm{C}=105^{\circ}, \mathrm{C}=\mathrm{C}-\mathrm{H}=120^{\circ}, \mathrm{H}-\mathrm{C}-\mathrm{C}=135^{\circ}$, H$\mathrm{C}-\mathrm{O}=123.872^{\circ}, \mathrm{O}-\mathrm{C}=\mathrm{C}=116^{\circ}$, torsion angle $=$ $0^{\circ}$.

\section{b) Memanggil data parameter atom.}

Untuk memanggil parameter atom-atom penyusun molekul tahapan yang dilakukan yaitu klik menu set up, pilih semiempirical dan klik, sehingga muncul kotak dialog semiempirical method. Klik PM3, lalu klik options, pilih metoda $R H F$, masukkan nilai convergence limit dan iteration limit. Klik OK.

\section{c) Mengaktifkan program bekerja.}

Untuk mengaktifkan program bekerja: Klik menu file, klik Start log, sehingga muncul kotak dialog, isikan nama file log, dan klik $O K$.

\section{d) Menjalankan program.}

Untuk menjalankan program, langkahlangkah di atas sudah harus dilakukan, 
selanjutnya lakukan langkah-langkah berikut klik menu compute, klik geometri optimization sehingga muncul kotak dialog semiempirical optimization, tentukan RMS gradient dan maximum cycles, Klik OK. Program akan bekerja otomatis, dan jika berhenti bekerja, klik menu file, pilih stop log. Sehingga didapatkan struktur furan yang telah dioptimasi yang sesuai dengan Gambar 2.

e) Membaca luaran data dalam keadaan optimal.

Ada 2 jenis luaran data: 1. Buka file log dengan notepad. Untuk luaran data ini dapat diamati Energi, Momen dipol, Grup simetri, koordinat kartesian, Atomic electron orbital population, net charge. Buka file hin dengan menggunakan hyperChem. Untuk luaran data ini dapat diamati panjang ikatan, sudut ikatan antaratom dan sudut antar bidang HOMO dan LUMO.

\section{f) Pembuatan polimer.}

Ambil data furan yang telah dioptimasi dengan cara klik menu file, pilih open sehingga muncul kotak dialog open file. Kemudian ambil menu file kembali, pilih merge dan klik, sehingga muncul kotak dialog merge file dan klik data furan yang kedua. Klik menu edit, pilih rotate sehingga muncul kotak dialog rotate, ketik nilai angle 180 untuk konformasi anti. Klik OK. Untuk mengatur torsion angle antar furan supaya 180, klik menu edit, pilih translate sehingga muncul kotak dialog translate. Pilih translate selection, other dan ketik nilai x dan y. Klik OK. Kemudian dioptimasi sesuai dengan prosedur $d$.

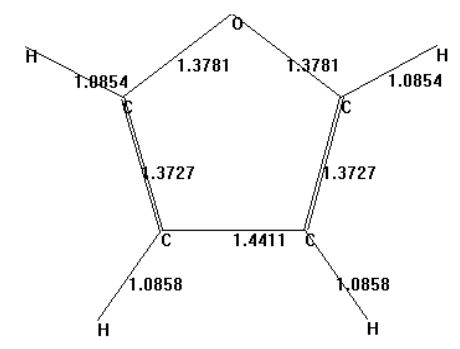

\section{Gambar 2. Geometri Akhir Atom-atom dalam Furan, panjang dalam Å menurut PM3}

Adapun skema prosedur yang dipilih dalam penelitian ini:

- Set up: semi-empirical method
a. Total charge $\quad: 0$
b. Spin multiplicity $\quad: 1$
c. Convergence limit: 0.001
d. Iteration limit $\quad: 50$
e. Spin pairing $\quad$ : RHF
f. State : Lowest

- Start log

Mechanics print level $=3$; Quantum print level $=3$

- Compute: Geometri optimization
a. Algorithm
: Polak-Riebe
b. RMS gradient of $=0,01 \mathrm{kCal} /(\mathrm{mol} \AA \hat{)})$

- Stop log

Selain data di atas, juga dibutuhkan nilai Highest Occupied molecular Orbital (HOMO) dan Lowest Occupied Molecular Orbital (LUMO) yang diperoleh dari hasil optimasi molekul polifuran dengan program PM3. Nilai HOMO dan LUMO digunakan untuk menentukan sifat elektronik molekul yang dihubungkan dengan nilai band gap $(\Delta \mathrm{E})$. Nilai band gap di cari dengan menggunakan persamaan berikut:

$\Delta E=\left(E_{\text {HOMO }}\right)-\left(E_{\text {LUMO }}\right)$

dimana $\mathrm{E}_{\text {номо adalah energi orbital tertinggi }}$ yang berisi elektron, dan $E_{\text {LUMO }}$ adalah energi orbital terendah yang tidak terisi elektron. Jika $\Delta \mathrm{E}>3 \mathrm{eV}$, molekul bersifat isolator, $\Delta \mathrm{E}=1-3$ $\mathrm{eV}$, molekul bersifat semikonduktor dan $\Delta \mathrm{E}<1$ $\mathrm{eV}$, molekul bersifat konduktor. Untuk menentukan seberapa besar ketepatan metoda yang digunakan, maka nilai overestimate harus ditentukan dengan/menggunakan persamaan berikut

Overestimate $=\left(\Delta E_{P M a}\right)-\left(\Delta E_{\text {Literatur }}\right)$

dimana $(\Delta \mathrm{E})$ PM3 $\quad$ adalah band gap metoda PM3, $(\Delta \mathrm{E})$ literatur adalah band gap literatur. Sistem yang dipelajari adalah polimer furan $\left(\mathrm{Fu}_{\mathrm{n}}\right.$, dimana $\mathrm{Fu}=$ furan dan $\mathrm{n}=$ jumlah cincin furan $1 \mathrm{~s} / \mathrm{d} 20$ ). Monomer furan berikatan satu dengan yang lain melalui atom $\mathrm{C} \alpha$ dengan konformasi anti ( atom O diletakkan berlawanan yaitu pada posisi $\theta=$ $180^{\circ}$ ). Polimer turunan furan konformasi anti (furan yang atom $\mathrm{H}$ posisi $\mathrm{C} \alpha$ nya di substitusi 
dengan substituen fenil $(\mathrm{Ph}), \quad$ radikal heksahalobenzena (-Z), radikal pirol (Py) dan tiofen (T).

\section{HASIL DAN PEMBAHASAN}

Optimasi Polimer Furan. Penelitian ini dilakukan dalam beberapa tahap pengerjaan, yaitu mengamati perubahan struktur, panjang ikatan, dan sudut ikatan

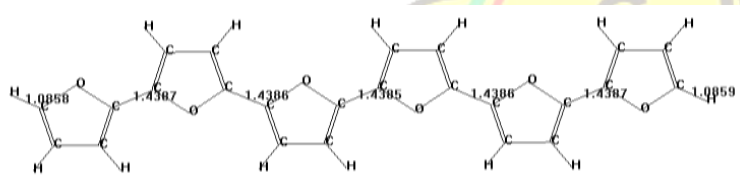

Gambar 3. Geometri akhir polifuran dengan jumlah cincin furan $n=6$

molekul polifuran murni dan turunannya (polifuran dengan substituen tertentu). Kemudian menganalisa data seperti sudut ikatan, panjang ikatan, perubahan nilai energi transisi elektronik $\left(\mathrm{E}_{\text {gap }}\right)$, dan energi ikatan (Binding Energy, BE) untuk mendapatkan sifat-sifat elektronik dari polifuran dan turunannya.

Hasil optimasi furan dengan menggunakan program PM3 (Gambar 3) memperlihatkan bahwa dalam kondisi optimal model ini termasuk kedalam grup simetri $\mathrm{C}_{2 \mathrm{v}}, \mathrm{C}_{2 \mathrm{~h}}$ dan CS. Menurut Oskuz, grup simetri yang dimiliki oleh oligomer berdasarkan nilai HOMO dan LUMO-nya, dapat dikategorikan ke dalam grup simetri $\mathrm{C}_{2 \mathrm{~h}}$ atau $\mathrm{C}_{2 \mathrm{v}}$ tergantung pada jumlah monomernya genap atau ganjil [8].

Dari hasil yang didapatkan terlihat bahwa cincin furan dengan $\mathrm{n}$ ganjil mempunyai grup simetri $\mathrm{C}_{2 \mathrm{v}}$ dan cincin furan dengan $\mathrm{n}$ genap mempunyai grup simetri $\mathrm{C}_{2 \mathrm{~h}}$. Hal ini sesuai dengan hasil yang dikerjakan oleh Oskuz (2004) dengan jumlah cincin furan $n=6$. Selain itu jarak ikatan antar monomer furan $(\mathrm{Fu})$ yang telah di optimasi hampir konstan yaitu 1,439 ̊ [8]. Perbedaan BE substituen antara dua polimer yang berurutan dari polifuran murni berkisar dari 847,991 s.d $-848,124 \mathrm{kcal} / \mathrm{mol}$.

Hal ini menunjukkan bahwa dalam proses pembentukan ikatan antar monomer yang berurutan akan mengalami kenaikan energi yang bernilai sama. Pada molekul Fu dengan $n=1-$
10 dimana $\mathrm{n}$ ganjil mempunyai grup simetri $\mathrm{C}_{2 \mathrm{v}}$ dan $\mathrm{n}$ genap mempunyai grup simetri $\mathrm{C}_{2 \mathrm{~h}}$ kecuali pada $\mathrm{n}=6$ dan $\mathrm{n}=8$ mempunyai grup simetri CS. Dapat dikatakan bahwa sistem oligomer Fu dengan konformasi anti memiliki geometri planar. Oksuz, juga mendapatkan hasil yang sama dengan mempelajari oligomer poliheterosiklik ( furan, tiopen, pirol) dengan jumlah monomer $\mathrm{n}=6$ [8]. Sedangkan untuk $\mathrm{n}=$ 11 s.d 20 mempunyai grup simetri CS, hal ini menandakan bahwa molekul polifuran dengan $\mathrm{n}$ $\geq 10$ kurang planar.

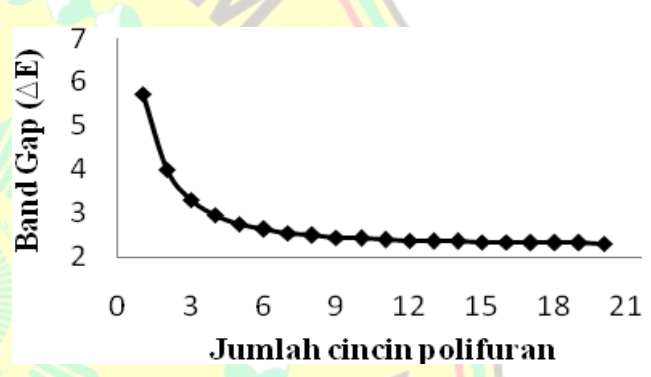

Gambar 4. Kurva korelasi nilai Egap terhadap jumlah cincin polifuran murni

Pada Gambar 4 terlihat bahwa ada hubungan antara jumlah monomer furan dengan nilai band gap $\left(E_{\text {gap }}\right)$. Semakin banyak jumlah monomer furan maka nilai HOMO dan LUMO semakin turun yang mengakibatkan nilai band gap ( $\left.\mathrm{E}_{\text {gap }}\right)$ juga semakin turun. Penurunan nilai $E_{\text {gap }}$ yang signifikan terjadi pada jumlah monomer $\mathrm{n}=1$ 10 dengan nilai $E_{\text {gap }}$ adalah $6.687 \mathrm{eV}$. Sedangkan pada $n=12 \mathrm{~s} / \mathrm{d} 20$ penurunan nilai $E_{\text {gap }}$ sangat kecil dan bisa dikatakan relatif konstan. Hal ini disebabkan oleh efek atom oksigen pada cincin furan yang bersifat

menarik elektron sehingga aliran elektron yang berkonjugasi terpengaruh, akibatnya aliran elektron menjadi agak lambat. Nilai $E_{\text {gap }} 6,687$ dijadikan sebagai limit $E_{\text {gap }}$ dari molekul polifuran murni karena perubahan nilai $\mathrm{E}_{\text {gap }}$ untuk jumlah cincin furan $\mathrm{n}>10$ tidak terlalu signifikan.

Optimasi Sistem $\mathbf{P h}-\mathrm{Fu}_{\mathrm{n}}-\mathbf{P h}$ atau $\mathbf{F u}_{\mathbf{n}}(\mathbf{P h})_{2}$. Sistem $\mathrm{Fu}_{\mathrm{n}}(\mathrm{Ph})_{2}$ dengan $\mathrm{n}$ ganjil dari cincin furan 1 s.d 10 memiliki grup simetri $\mathrm{C}_{2 \mathrm{v}}$ sedangkan $\mathrm{n}$ genap memiliki grup simetri $\mathrm{C}_{1}$ dan CS. Pada cincin furan dengan $\mathrm{n} \geq 10$ sistem $\mathrm{Fu}_{\mathrm{n}}(\mathrm{Ph})_{2}$ memiliki grup simetri CS. Hal ini menandakan 
bahwa molekul kurang planar terutama sekali cincin furan $n \geq 10$. Selain itu juga dapat dilihat nilai $\mathrm{BE}$ substiuen sistem $\mathrm{Fu}_{\mathrm{n}}(\mathrm{Ph})_{2}$ hampir sama yaitu berkisar 1208,282 - 1208,445 kkal/mol. Nilai BE sistem lebih besar dari BE polifuran murni. Sehingga dalam pembentukan ikatan polimer dengan substituen $\mathrm{Ph}$ membutuhkan energi yang besar. Gambar 5 memperlihatkan perubahan $\mathrm{E}_{\text {gap }}$ dari polifuran cincin 1 s.d 20 dengan dan tanpa substituen fenil. Penambahan substituen fenil dapat menurunkan nilai $E_{\text {gap }}$ dari polifuran. Penurunan yang tajam terjadi pada $n=$ 1 s.d 6 dan untuk $n \geq 6$ turun perlahan sampai pada limit tertentu. Limit $\mathrm{E}_{\text {gap }}$ untuk sistem $\mathrm{Fu}_{\mathrm{n}}(\mathrm{Ph})_{2}$ adalah 6,652 eV. Nilai $\mathrm{E}_{\text {gap }}$ ini lebih rendah dari $\mathrm{E}_{\text {gap }}$ polifuran murni, hal ini berarti bahwa penambahan substituen fenil cukup efektif untuk menurunkan $\mathrm{E}_{\text {gap }}$ molekul polifuran.

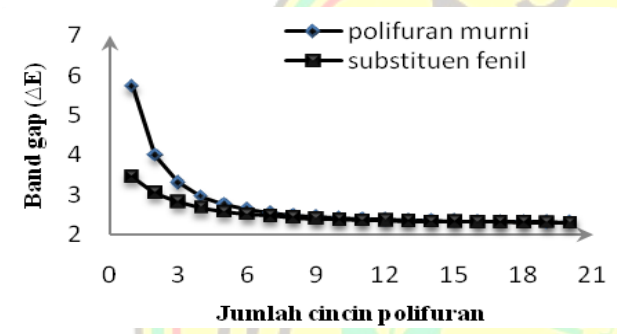

Gambar 5. Kurva korelasi nilai Egap terhadap cincin polifuran dengan substituen fenil.

Optimasi Sistem $Z$-F $u_{n}-Z$ atau $F_{n}(Z)_{2}$ dan $F_{u_{n}-}$ $\mathbf{Z}-\mathbf{F} \mathbf{u}_{\mathbf{n}}$. Grup simetri dari polifuran dengan substituen heksahalobenzena pada posisi ujung adalah $\mathrm{C}_{2 \mathrm{v}}, \mathrm{C}_{2 \mathrm{~h}}, \mathrm{CS}, \mathrm{C}_{2}$ dan $\mathrm{C}_{1}$. Terlihat bahwa molekul polifuran yang tersubstitusi dengan heksahalobenzena pada posisi ujung mengalami perubahan yaitu cenderung melengkung karena sudut ikatan antara monomer furan dengan monomer berikutnya semakin besar (sudut O-CC).

Pada substituen heksaiodobenzena molekul tidak satu bidang lagi membentuk sudut (tegak terhadap bidang). Hal ini disebabkan oleh perbedaan tarikan elektron dan terdelokalisasi pada molekul heksahalobenzena serta massa molar molekul heksahalobenzena yang besar.

Perubahan nilai $E_{\text {gap }}$ dari polifuran cincin 1 s.d 20 dengan substituen heksahalobenzena posisi ujung dapat dilihat pada Gambar 6. Penambahan substituen heksahalobenzena secara umum dapat menurunkan nilai $\mathrm{E}_{\text {gap }}$ polifuran. Penurunan yang sangat signifikan terjadi pada substituen heksafluorobenzena hingga mencapai nilai terendah yaitu $6,295 \mathrm{eV}$ dengan simetri $\mathrm{C}_{2 \mathrm{~h}}$. Namun untuk nilai limit $E_{\text {gap }}$ harus di ambil dengan jumlah cincin yang sama yaitu $\mathrm{n}=10$ adalah $6,331 \mathrm{eV}$ dan merupakan nilai yang terendah dari substituen halobenzena yang lainnya.

Sedangkan substituen heksaiodobenzena terjadi kenaikan nilai $\mathrm{E}_{\text {gap }}$ dari $\mathrm{n}=1$ menuju $\mathrm{n}=2$ kemudian turun kembali hingga mencapai limit 6,552 eV. Hal ini disebabkan oleh perbedaan kestabilan substituen. Karena ikatan yang terjadi antara $\mathrm{C}$ benzena dengan $\mathrm{F}$ lebih kuat dibandingkan dengan $\mathrm{Cl}, \mathrm{Br}$ dan $\mathrm{I}$ yang disebabkan kelektronegatifannya yang besar. Akibatnya ikatan yang terjadi akan lebih sulit untuk diputuskan. Heksahalobenzena termasuk pendorong elektron namun gugus halogen yang berikatan dengan benzena mengakibatkan inti benzena terdeaktivasi sehingga inti benzena lebih stabil. Selain itu Nilai limit $E_{\text {gap }}$ untuk heksaklorobenzena dan heksabromobenzena adalah 6.667 dan $6.579 \mathrm{eV}$, dimana nilainya lebih rendah dari nilai $\mathrm{E}_{\text {gap }}$ polifuran murni.

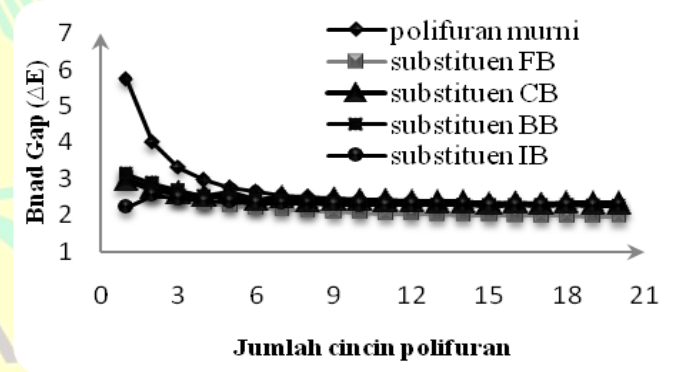

Gambar 6. Kurva korelasi nilai Egap terhadap cincin polifuran murni dan polifuran dengan substituen molekul heksahalobenzena posisi ujung

Polifuran substituen heksahalobenzena posisi tengah mempunyai grup simetri $\mathrm{C}_{2 \mathrm{~h}}, \mathrm{CS}$, $\mathrm{C}_{1}, \mathrm{C}_{2}$ dan $\mathrm{C}_{\mathrm{I}}$. Grup simetri $\mathrm{C}_{2 \mathrm{~h}}$ umumnya terdapat pada setiap substituen heksahalobenzena pada cincin polifuran $n=2$ dan 4 kecuali untuk heksafluorobenzena juga terdapat pada $\mathrm{n}=8,12$ 
dan 14. Hal ini berarti bahwa polifuran substituen heksahalobenzena tidak akan planar dengan bertambahnya cincin polifuran. Dari geometri yang terbentuk, molekul polifuran tidak sebidang dengan substituen heksahalobenzena (tegak lurus terhadap bidang ). Penurunan nilai $E_{\text {gap }}$ polifuran yang signifikan masih terjadi pada substituen heksafluorobenzena hingga mencapai limit 6,229 $\mathrm{eV}$.

Untuk sistem heksaklorobenzena dan heksaiodobenzena penurunan nilai $E_{\text {gap }}$ yang signifikan terjadi pada jumlah cincin furan 2 s.d 6 (Gambar 7). Sistem heksafluorobenzena dan heksabromobenzena secara keseluruhan memiliki nilai $E_{\text {gap }}$ yang lebih rendah dibandingkan dengan polifuran murninya. Secara umum, heksahalobenzena dapat menurunkan nilai $\mathrm{E}_{\text {gap }}$ tapi menyebabkan terjadinya perubahan geometri molekul sehingga tidak planar lagi. Hal ini menyebabkan sistem tersebut kurang baik digunakan sebagai semikonduktor.

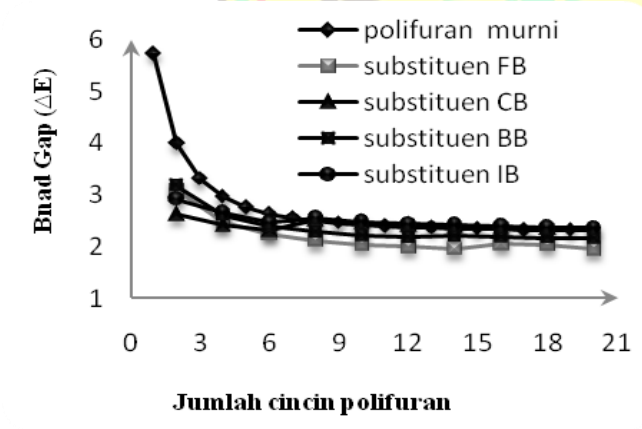

\section{Gambar 7. Kurva korelasi nilai Egap terhadap cincin polifuran murni dan polifuran dengan substituen molekul heksahalobenzena posisi tengah}

Optimasi Sistem Py-Fun $-\mathrm{Py}$ atau $\mathrm{Fu}_{\mathrm{n}}(\mathrm{Py})_{2}$. Data hasil optimasi polifuran dengan substituen pirol posisi ujung sistem $\mathrm{Fu}_{\mathrm{n}}(\mathrm{Py})_{2}$. dilihat bahwa ada keteraturan secara umum dalam grup simetri substituen pirol, dimana untuk $\mathrm{n}$ ganjil memiliki grup simetri $\mathrm{C}_{2 \mathrm{v}}$ dan $\mathrm{n}$ genap memiliki grup simetri $\mathrm{C}_{2 \mathrm{~h}}$. Hal ini menunjukkan bahwa sistem $\mathrm{Fu}_{\mathrm{n}}(\mathrm{Py})_{2}$ planar dibandingkan substituen yang lain. Hal yang sama juga terjadi pada substituen metil. Selain itu dapat dilihat nilai BE substituen hampir sama yaitu berkisar dari 925,555 -
922,655 kkal/mol. Dilihat dari energinya yang tinggi, reaksi pembentukan ikatan sulit terbentuk

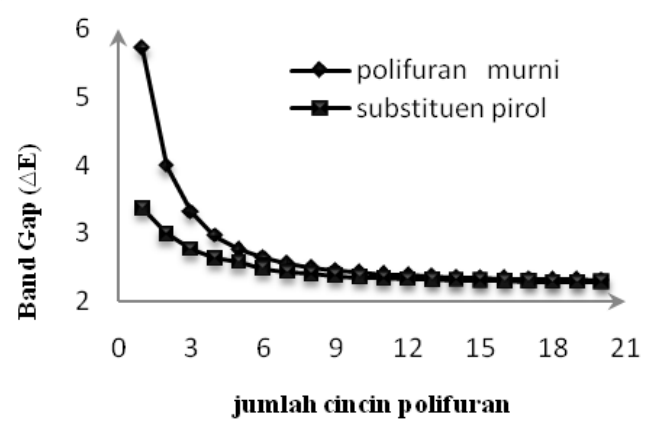
Gambar 8. Kurva korelasi nilai Egap terhadap cincin polifuran murni dan polifuran dengan substituen pirol

Gambar 8 memperlihatkan perubahan nilai $E_{\text {gap }}$ polifuran cincin 1 s.d 20 dengan substituen pirol. Penambahan substituen pirol pada posisi ujung dapat menurunkan nilai $\mathrm{E}_{\text {gap }}$ dari polifuran murni. Penurunan yang signifikan terjadi pada cincin $n=1$ s.d 6 dan cincin dengan $n \geq 6$ turun perlahan sampai pada limit tertentu. Limit Egap sistem $\mathrm{Fu}_{\mathrm{n}}(\mathrm{Py})_{2}$ adalah 6,623 eV. Nilai ini lebih rendah dibandingkan dengan nilai $\mathrm{E}_{\text {gap }}$ polifuran murni tetapi lebih tinggi dari nilai $\mathrm{E}_{\text {gap }}$ sistem $\mathrm{Fu}_{\mathrm{n}}\left(\mathrm{NH}_{2}\right)_{2}$. Hal ini berarti sistem $\mathrm{Fu}_{\mathrm{n}}(\mathrm{Py})_{2}$ bisa digunakan sebagai bahan semikonduktor.

Optimasi Sistem (T-Fu) $)_{\mathbf{n}}$ dan Sistem $(\mathrm{Fu}-\mathrm{T})_{\mathrm{n}}$. Hasil optimasi sistem $(\mathrm{T}-\mathrm{Fu})_{\mathrm{n}}$ dan $(\mathrm{Fu}-\mathrm{T})_{\mathrm{n}}$. Grup simetri dari sistem (T-Fu)n dan (Fu-T)n adalah $\mathrm{CS}$ dan $\mathrm{C}_{2 \mathrm{v}}$. Kedua sistem ini mempunyai keteraturan grup simetri yaitu CS untuk sistem $(\mathrm{T}-\mathrm{Fu})_{\mathrm{n}}$ dan $(\mathrm{Fu}-\mathrm{T})_{\mathrm{n}}$ dengan jumlah cincin $\mathrm{T}=\mathrm{Fu}$ dan grup simetri $\mathrm{C}_{2 \mathrm{v}}$ untuk $\mathrm{T}>\mathrm{Fu}$ atau $\mathrm{Fu}>\mathrm{T}$. Kedua sistem $(\mathrm{T}-\mathrm{Fu})_{\mathrm{n}}$ dan $(\mathrm{Fu}-\mathrm{T})_{\mathrm{n}}$ bentuknya cenderung melengkung dengan semakin banyaknya cincin $\mathrm{T}$ dan $\mathrm{F}$ yang berikatan. Hal ini berarti sitem ini tidak lagi berbentuk planar. Atom $\mathrm{O}$ dan $\mathrm{S}$ yang bersifat elektronegatif berkemungkinan besar akan berikatan dengan $\mathrm{H}$ dari cincin sehingga membentuk ikatan hidrogen intramolekul (Wikipedia, polimer 2007). Ikatan yang terbentuk akan menyebabkan struktur dari polimer akan mengalami perubahan. Semakin banyak cincin furan atau tiopen, maka struktur molekul akan melengkung. Dengan terbentuknya ikatan hidrogen, maka kelarutannya akan 
berkurang dalam pelarut organik dan struktur memiliki massa molekul relatif yang cukup besar. $\mathrm{BE}$ substituen dari sistem ini cenderung naik dengan penambahan jumlah cincin furan ataupun tiopen yaitu dari 409.659 s.d $1622.245 \mathrm{kcal} / \mathrm{mol}$ untuk T-Fu dan 409.659 s.d $2046.221 \mathrm{kcal} / \mathrm{mol}$ untuk sistem Fu-T.

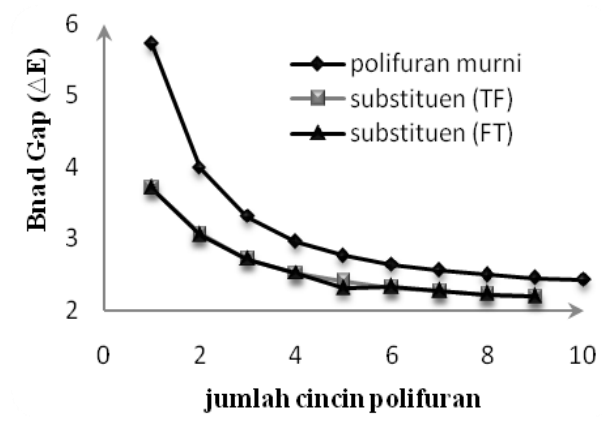

Gambar 9. Kurva korelasi nilai Egap terhadap cincin polifuran murni dan kombinasi furan-tiopen

Pada Gambar 9 memperlihatkan perubahan nilai $E_{\text {gap }}$ dari sistem $(\mathrm{T}-\mathrm{Fu})_{\mathrm{n}}$ dan $(\mathrm{Fu}-\mathrm{T})_{\mathrm{n}}$. Komposisi dari furan dan tiopen dalam sistem ( $\mathrm{T}$ $\mathrm{Fu})_{\mathrm{n}}$ dan $(\mathrm{Fu}-\mathrm{T})_{\mathrm{n}}$ efektif untuk menurunkan nilai $E_{\text {gap }}$ polifuran dengan nilai 6.458 dan $6.459 \mathrm{eV}$. Namun komposisi sistem $(\mathrm{T}-\mathrm{Fu})_{\mathrm{n}}$ dan $(\mathrm{Fu}-\mathrm{T})_{\mathrm{n}}$ yang cenderung melengkung (tidak planar) dengan pertambahan cincin furan / tiopen kurang bagus untuk bahan semikonduktor.

Pada sistem polifuran murni $\left(\mathrm{Fu}_{\mathrm{n}}\right)$ yang diselidiki ternyata sistem dengan jumlah cincin furan $n=1 \mathrm{~s} / \mathrm{d} 3$ memiliki nilai $\mathrm{E}_{\text {gap }}>3$ dan $\mathrm{n}=4$ s/d 20 memiliki nilai $E_{\text {gap }}<3$. Hal ini berarti furan, bifuran dan terfuran bersifat isolator sedangkan untuk $n=4$ (quarterfuran) hingga $n=$ 20 sitem bersifat semikonduktor. Namun, untuk jumlah cincin furan $n>10$ sistem memiliki geometri yang kurang planar. Sehingga sistem akan lebih efektif digunakan sebagai semikonduktor organik adalah furan dengan jumlah cincin furan $n \leq 10$ (oligofuran). Karena semikonduktor organik yang diinginkan adalah yang memiliki geometri planar dan $E_{\text {gap }}$ yang rendah [9].

Nilai band gap (Egap) sistem turunan polifuran (1 atau 2 atom $\mathrm{H}$ furan pada $\mathrm{C} \alpha$ di substitusi dengan substituen tertentu) juga mengalami penurunan. Untuk semua sistem turunan polifuran dengan jumlah cincin $n=1 \mathrm{~s} / \mathrm{d}$ 3 secara umum memiliki nilai $\mathrm{E}_{\text {gap }}>3$ dan $\mathrm{n}=4$ s/d 20 memiliki nilai $E_{\text {gap }}<3$. Berdasarkan geometri turunan polifuran hasil penelitian didapatkan geometri molekul sebagai berikut:

1. Fenil dengan bentuk sistem $\mathrm{Ph}-\mathrm{Fu}_{\mathrm{n}}-\mathrm{Ph}(\mathrm{Ph}=$ fenil) memiliki geometri planar untuk jumlah cincin furan $n=1 \mathrm{~s} / \mathrm{d} 10$.

2. Radikal heksahalobenzena yang kehilangan atom $\mathrm{H}$ nya

a. Radikal heksahalobenzena yang kehilangan satu atom halogennya dengan bentuk sistem $\quad \mathrm{Z}-\mathrm{Fu}_{\mathrm{n}} \mathrm{Z} \quad\{\mathrm{Z}=$ heksahalobenzena, $\quad Z=\quad F B$ (heksafluorobenzena), $\quad \mathrm{CB}$ (heksaklorobenzena), $\quad \mathrm{BB}$ (heksabromobenzena) dan IB (heksaiodobenzena)\} memiliki geometri kurang planar.

b. Radikal heksahalobenzena yang kehilangan dua atom halogennya dengan bentuk sistem $\mathrm{Fu}_{\mathrm{n}}-\mathrm{Z}-\mathrm{Fu}_{\mathrm{n}}$ memiliki geometri kurang planar.

3. Radikal pirol yang kehilangan atom $\mathrm{H}$ nya dengan bentuk sistem $\mathrm{Py}-\mathrm{Fu}_{\mathrm{n}}-\mathrm{Py}(\mathrm{Py}=$ pirol $)$ memiliki geometri yang planar

4. Radikal tiofen / furan dengan sistem $(\mathrm{T})_{\mathrm{n}} \mathrm{Fu}$. $(\mathrm{T}=$ tiofen $)$ dan $(\mathrm{Fu})_{\mathrm{n}} \mathrm{T}$ memiliki geometri yang kurang planar dan cenderung melengkung.

\section{KESIMPULAN}

Berdasarkan studi mengenai penggunaan metoda PM3 untuk mempelajari struktur dan sifat polifuran, maka dapat disimpulkan bahwa hampir semua sistem yang dipelajari bersifat semikonduktor. Hasil pengoptimasian struktur turunan polifuran memperlihatkan bahwa seluruh substituen yang digunakan dapat menurunkan nilai band gap $\left(E_{\text {gap }}\right)$ polifuran. Nilai band gap $\left(E_{g a p}\right)$ ternyata dipengaruhi oleh jumlah cincin furan yang berikatan membentuk polimer. Semakin banyak jumlah cincin furan maka keefektifan substituen dalam menurunkan band gap relatif kecil. Penurunan nilai band gap yang signifikan terjadi pada jumlah monomer furan $\mathrm{n}$ $=1$ s.d 10. Optimasi dengan metoda PM3 
memiliki nilai overestimate berkisar dari 3,612 $4,269 \mathrm{eV}$

\section{DAFTAR PUSTAKA}

Espoti, A. S, and M. Brandle, (1997), A Density Functional Study of The Vibrations of Three Oligomer of Thiophene, J. Phys. Chem., A, 101:7283-7291.

Adant, C., and M. Dupuis (1997, An Ab Initio and Semiempirical Study of of The First and ThirdOrder Polarizabilities in Benzene and Thiophene Derivater: Electron Corrrelation Effect, J. Phys. Chem., 101: 3025-3031.

Forni, Alessandra, Sironi, Maurizio and Raimondi, Mario, (1997), Theoritical Investigation of Thiophene Oligomers: A Spin-Coupled Study., J. Phys. Chem., A, 101: 4437-4443.

Nabutoki, and Koezuka, (1996), Molecular Orbital Study on Electron Confinement Characteristics in Heteroaromatic Oligomers, J. Phys. Chem., 100: 6451-6455.

Hong, Sung Y., and Song, M., Jung, (1997), Quantum-Chemical Study of Geometrical and Electronic Structure of Thiphene-Based
Bicyclic Polymers, J. Phys. Chem., B, 1101: 10248-10253.

Blanca, E., I. Carrillo, M. J. Gonzalez-Tejera and I. Hermandez-Fuentez. 2000. J. polym. Sci., part. A: Polymer Cehmistry, 38: 291.

Oskuz, Nevin, (2004), Quantum Chemical Study of Geometrical and Electronic Structures of Aromatic Five-Membered Heterocyclic Oligomers in The Ground and Lowest Singlet Excited States., Middle East Technical University

Angelca de Valle, M., R. D. Fernando and J. C. Bernede (2004), Nucleation and Growth mechanisms of Poly(furan). Effect of Electrlyte and Monomer Concentration in Aceetinitrile. J. Braz. Chem. Soc., 15: 272276.

Reyes, R. V., L. D. Mercado, J. Anaya-Gil, A. G. Marrugo and E. Martinez, (2008), Theoritical study to Evaluate Polyfuran Electrical Conductivity and Methylamine, Methoxy Substituent Effects, J. Mol. Struct. (THEOCHEM). 